\title{
Welfare Analysis of Lifting the GM Ban in Russia
}

\author{
S. Chetvertakov \\ Institute of Farm Economics, Thunen-Institut, Germany
}

\begin{abstract}
Use of genetically modified crops is prohibited in Russia, however, Russian politicians are currently discussing this technology. This article evaluates the potential welfare effects of adopting genetically modified crops in Russia, focusing on the potential benefits to Russian producers who adopt herbicide tolerant corn and soybeans. Calculations are based on supply and demand functions of current market situations and their potential shifts. The results quantify the potential monetary gains from open markets to genetic engineering technology and explain the potential additional costs related to technology adoption.
\end{abstract}

\section{Keywords}

Welfare analysis, GM, corn, soybeans, Russia

Chetvertakov, S. (2016) "Welfare Analysis of Lifting the GM Ban in Russia", AGRIS on-line Papers in Economics and Informatics, Vol. 8, No. 2, pp. 49-56. ISSN 1804-1930. DOI: 10.7160/aol.2016.080204.

\section{Introduction}

The battle of sanctions that began in 2014 between the Russian Federation and its some trade partners resulted in constraints for the entire Russian economy, and it especially affected the agricultural sector. Maintenance of economy required from the government initiation of anti-crisis activity to stabilize the economy (Gov (b), 2015), but they were unsuccessful in controlling the weakening economy. The national currency fell and the Central Bank raised the interest rate. Higher interest rates and the growing inflation rate demanded changes to the current level of agricultural subsidies (Gov (a), 2015). In the face of government financial constraints, which are the results of sanctions on Russia, an important question can be raised: what alternative sources can be used to support agricultural producers?

Widespread innovations such as genetically modified seeds cannot be applied legally in Russia, despite demand for this technology from the production sector. In 2012, a law that would open the gate for genetically modified (GM) crops was proposed (MEDRF, 2012), but did not pass. Political discussion regarding adoption of GM seeds inclines to the position of GM opponents and Russian policy-makers, employing the argument of unpredictable outcomes for human health and the environment, kept GM seeds out of Russia (Lenta, 2015; Kommersant, 2015). In Russia and other countries that prohibit the production of GM crops, there is particular interest in economic compensation for the welfare losses resulting from these market constraints (Moschini et. al., 2000).

The possible effects of GM crop adoption have been calculated for many regions and different crops (Trigo and Cap, 2004; Raney, 2006). Brookes and Barfoot (2014) argue that the main reason for the current adoption of GM herbicide tolerant (HT) crops has been lower production costs. Although there is some evidence of a yield advantage (Brookes and Barfoot, 2014), this effect cannot be generalized (Finger et al., 2011).

Potential welfare effects of GM seed adoption in the Russian economy have not been studied. This paper estimates the welfare changes of Russian producers in the case of access to GM seeds. The specific focus of the study is HT corn and soybeans.

Particular interest in substituting GM corn and soybeans for conventional varieties stems from the fast acreage expansion of these crops and their growing importance in Russian agriculture. The average annual growth rate (2000-2013) for both crops was $10.2 \%^{1}$ across Russia. In this same period, average annual growth rates reached $17.3 \%$ and $32.8 \%$ for corn and soybeans, respectively, in the Central Federal District, one of country's main agricultural regions.

Insect resistant corn was also considered

'Own calculation based on official statistics from UniSis database, 2015. 
for the study, but there is a relative lack of necessary data. First of all, the effects of insect resistant corn use depend significantly on pest infestation levels (Baute et. al., 2002). Some regional studies (Potemkina and Lastushkina, 2006; Serapionov and Frolov, 2008) do not track pest infestation levels in corn growing regions. Secondly, few studies include economic performance figures of farms using Bt corn (Finger et al., 2011), making economic analysis difficult. Finally, there is also considerable ambiguity about the yield effects of using Bt corn (Finger et al., 2011). All of these make estimating the welfare effects of Bt corn in Russia difficult.

This paper is organized as follows: the second section describes and discusses methods which will be used in the paper; the third section provides the results. The discussion regarding the pitfalls of the GM legislation and conclusion will finalize the paper.

\section{Materials and methods}

Russian corn and soybean market models are assumed to take the following functional forms, following the linear supply and demand equations:

$$
\begin{aligned}
& \mathrm{D}(\mathrm{Q})=\mathrm{P}=\mathrm{a}_{0}+\mathrm{a}_{1} \mathrm{Q}^{\mathrm{d}} \\
& \mathrm{S}(\mathrm{Q})=\mathrm{P}=\mathrm{b}_{0}+\mathrm{b}_{1} \mathrm{Q}^{\mathrm{s}}
\end{aligned}
$$

The starting point of model construction is estimating the current situation. Calculation of the demand and supply equations requires initial data that was taken from three sources: production and trade data (total production, consumption, exports, imports, etc.) for 2013/2014 growing season $^{2}$ come from the USDA database (2015); Russian corn and soy supply and demand elasticities come from the FAPRI Elasticity Database (2015); the average prices in Russia for the selected season were gathered (and then converted to US dollars) from UniSis database (2015).

\section{Corn}

Corn balance in 2013/2014 was as follows: total supply ${ }^{3}$ was $\mathrm{Q}_{0}^{\mathrm{s}}=11,642 \mathrm{mln}$. metric tons (MT), total demand (consumption) $\mathrm{Q}_{\mathrm{dc}}=7,500 \mathrm{mln}$. MT and net export 4,142 mln. MT. Supply elasticity (area) is equal to $\mathrm{e}_{\mathrm{s}}=0.31$. Average price for the season was $\mathrm{P}=\$ 173.56$ per MT. There

\footnotetext{
${ }^{2}$ The local marketing year for Russia for corn and soybeans is October 2013 to September 2014

3 Calculated as the sum of beginning stocks and production less ending stocks.
}

are two demand elasticities based on the two uses of corn for animal feed and human consumption. As the majority of the total consumption (88\%) is used for animal feeding, the author employs the elasticity relative to this use, which is equal to $e_{d}=-0.2$. It is also possible to calculate one demand elasticity based on the two uses or apply other solutions, but as will be explained later, demand elasticity does not influence the consumer welfare alteration.

Given the above values, it is possible to derive the four unknowns in the supply and demand equations:

$\mathrm{a}_{1}=\left(\frac{1}{\mathrm{e}_{\mathrm{d}}}\right) \times\left(\frac{\mathrm{P}}{\mathrm{Qdc}_{\mathrm{dc}}}\right)$

$\mathrm{a}_{0}=\mathrm{P}-\mathrm{a}_{1} \mathrm{Q}^{\mathrm{d}}$

Substituting $\mathrm{b}_{0}$ and $\mathrm{b}_{1}$ for $\mathrm{a}_{0}$ and $\mathrm{a}_{1}$, respectively, the necessary parameters for the supply function are also calculated. The demand and supply curves are drawn in Figure 1. Further calculations reveal the $\mathrm{x}$-intercept of the supply function $\mathrm{S}_{0}$ and horizontal axis, which is $\mathrm{Q}_{0}$ equal to $8,033 \mathrm{mln}$. MT. Lifting the GM ban will lead to cost savings, which will shift the supply curve $\mathrm{S}_{0}$ downward to $\mathrm{S}_{1}$.

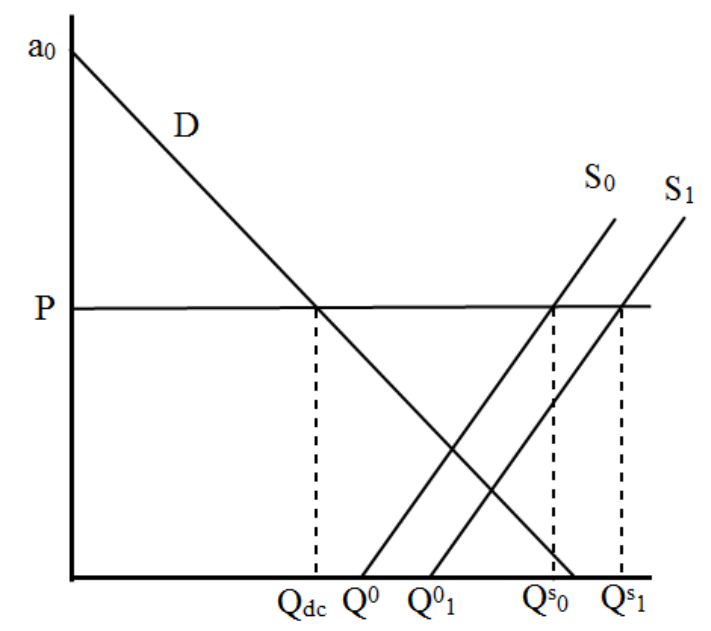

Source: own processing

Figure 1. Corn market in 2013/2014

In this paper the author applies a small-country assumption: such that Russian production and trade policies does not affect the world market price. Therefore, the world demand for Russian corn is perfectly elastic and as long as domestic market is a world price taker, domestic consumer's welfare does not change due to the supply shift. However, there is another way of modelling the market. Moschini et al. (2000) employed 
a partial equilibrium model by measuring demand elasticities of importing countries. This method was not used because of two limitations:

1. The lack of quantity and destination data of corn exports (the UN Comtrade Database (2015) was considered as the source of such information, but was rejected due to limitations explained on their webpage).

2. Russia exports a negligible amount of corn relative to the world market and thus a slight increment of export quantities does not influence the world market.

One of the key challenges is quantifying the cost savings from the adoption of GM crops. Climate conditions do not influence on the economic performance of GM crops in comparison to conventional (Finger et al., 2011), which seems logic as trading by GM seeds and treatment materials companies adjust prices to the potential farmer's return. Hence, climate conditions are not considered to have an effect on crop production costs, and therefore, cost-savings resulting from use of GM or conventional seeds.

The paper from Brookes and Barfoot (2014) presents a summary of economic impacts of GM crops over many countries. Income benefits resulting from both lower input costs (cost savings) as well as yield gains will be considered in this study. Although Finger et al. (2011) argue that yield increase of GM crops cannot be generalized, this factor cannot be ignored. Therefore, yield gains are included in the calculation of the monetary benefits of GM use, but conventional and GM crop yields were assumed to be the same for the calculation. Different benefit level will reflect the sensitivity of the welfare in depends to the average farm benefit, which differs from year to year due to fluctuation in price of herbicide, seed cost, cost of technology and yield. The lowest (\$1 per hectare in South Africa) and the highest (\$90 per hectare in Argentina) values of the farm income benefit (after deduction of cost of technology) will be the limits.

Welfare effects of open access to GM seeds in Russia compared to the current situation can be measured as geometric areas. Current consumer surplus CSA is the area below the demand curve D and above the price $\mathrm{P}$ :

$\mathrm{CS}^{\mathrm{A}}=\frac{1}{2}\left(\mathrm{a}_{0}-\mathrm{P}\right) \times \mathrm{Q}_{\mathrm{dc}}$

Current producer surplus PS $^{\mathrm{A}}$ can be measured as the area above the current supply curve $S_{0}$ and below the price $\mathrm{P}$ :

$$
\begin{aligned}
\mathrm{PS}^{\mathrm{A}}=\left(\mathrm{Q}^{0} \times \mathrm{P}\right) & +\frac{1}{2}\left(\left(\mathrm{Q}_{0}^{\mathrm{S}}-\mathrm{Q}^{0}\right) \times \mathrm{P}\right) \\
& =0.5 \mathrm{P}\left(\mathrm{Q}_{0}^{\mathrm{S}}+\mathrm{Q}^{0}\right)
\end{aligned}
$$

After potential change in the Russian legislation the supply curve will move downward, increasing producer surplus. This amount will be calculated as income benefit per ha divided by the actual yield (5.01 MT per ha). This figure will reflect the income benefit per metric ton basis. The new supply curve function will be:

$\mathrm{S}_{1}(\mathrm{Q})=\mathrm{P}=\mathrm{b}_{0}-\mathrm{c}+\mathrm{b}_{1} \mathrm{Q}_{1}^{\mathrm{s}}$

where $\mathrm{c}$ is the amount of income benefits in US dollars per metric ton and $\mathrm{Q}^{\mathrm{S}}$ is a new supplied amount.

New producer surplus PS $^{\mathrm{N}}$ can be calculated as:

$$
\begin{aligned}
\mathrm{PS}^{\mathrm{N}}=\left(\mathrm{Q}_{1}^{0} \times \mathrm{P}\right) & \left.+\frac{1}{2}\left(\mathrm{Q}_{1}^{\mathrm{S}}-\mathrm{Q}_{1}^{0}\right) \times \mathrm{P}\right) \\
& =0.5 \mathrm{P}\left(\mathrm{Q}_{1}^{\mathrm{S}}+\mathrm{Q}_{1}^{0}\right)
\end{aligned}
$$

\section{Soybeans}

Unlike corn, soy is a scarce commodity in Russia and the domestic production provides only half of the total domestic consumption. Total domestic supply ${ }^{4}$ of soybeans in 2013/2014 was $\mathrm{Q}^{\text {sd }}{ }_{0}=1,453 \mathrm{mln}$. MT, net import $1,907 \mathrm{mln}$. MT and the total domestic consumption $\mathrm{Q}_{\mathrm{dc}}=3,360 \mathrm{mln}$. MT. Supply elasticity (area) is not specified for Russia in the FAPRI database, so the elasticity for CIS $^{5}$ countries is used, which is $\mathrm{e}_{\mathrm{s}}=0.42$. Average price for the marketing season is $\mathrm{P}=\$ 504.97$ per MT. Demand represents two components: feed demand and demand for crushing, and there is absence of consolidated demand elasticity for beans. Author uses Moschini et al. (2000) calculations of bean elasticity for the rest of the world, which is $e_{d}=-0.4$. However, as in the case of corn, the small country assumption will be applied and consumer welfare will not change due to the supply move.

Exploiting equations (3) and (4), it is possible to calculate the supply and demand functions (figure 2). Further calculations are used to derive the crossing point of supply function $\mathrm{S}_{0}$ and horizontal axis, which is $\mathrm{Q}_{0}=842.7 \mathrm{mln}$. MT.

Net gains from planting GM herbicide tolerant soybeans are difficult to estimate as the effect of the following crop may also have an impact. A paper by Brookes and Barfoot (2014) simulate a range of possible net farm benefits from GM

\footnotetext{
${ }^{4}$ treated the same manner as corn supply

5 The Commonwealth of Independent States
} 
technology in several countries and different GM technologies. The minimum farm income benefit was observed in South Africa and equal to \$4 per hectare ( $1^{\text {st }}$ generation GM HT soybeans) and the highest was $\$ 149$ in the US ( $2^{\text {nd }}$ generation GM HT soybeans). This range of benefits will be used to calculate the potential welfare gain.

Equations 5-8 presented in the corn part can be employed to measure soybean welfare as well. Amount of the benefits per ton is calculated by dividing net gains from GM per hectare by the yield level of the selected season, which was $1.36 \mathrm{MT} / \mathrm{ha}$.

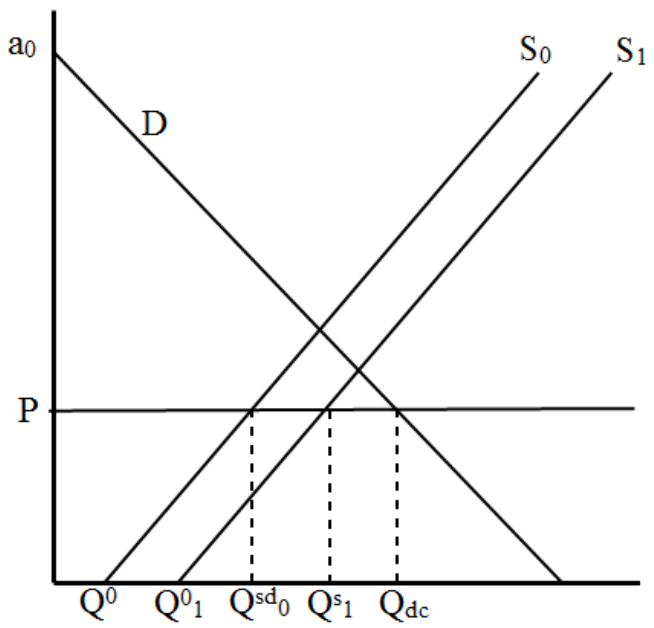

Source: own processing

Figure 2. Soybean market in 2013/2014.

\section{Results and discussion}

\section{Corn}

First, consumer and producer surplus are calculated for the current situation of no access to GM seeds.
Corn consumers have surplus equal to $\$ 3,254 \mathrm{mln}$., and corn producer surplus is $\$ 1,707 \mathrm{mln}$. Sequentially, by substituting income benefits into equation (7), and then subtracting current producer surplus from potential producer surplus, change in the producer welfare, $\triangle \mathrm{PS}$, is found. The results for selected amounts of income benefits per hectare relative to the potential adoption rate of GM corn in Russia are presented in Table 1. Adoption rate was applied to indicate the different welfare outcomes. Lifting the GM ban would not lead immediately to wide acceptance by farmers. The number of producers who will use GM seeds will affect the total producer surplus area.

Increase of producer surplus is a result of growth in supply. For example, with $\$ 30$ per ha of income benefit and 100\% technology adoption, producer supply will increase by 124.5 thousand MT (going to export) which leads to additional $\$ 21.6 \mathrm{mln}$. in producer surplus at a price of $\$ 173.56$ per MT.

\section{Soybeans}

Russian soybean consumers benefit from the world market price as it is located below the domestic market price. Their current consumer surplus is equal to $\$ 4,242 \mathrm{mln}$., while producer surplus is only $\$ 580 \mathrm{mln}$. Possible welfare gains from access to GM HT soybeans are reflected in Table 2. Income benefits will slightly affect the quantity of soybeans produced domestically. With $\$ 50$ per ha benefit from GM technology, soybean growers would be ready to increase soybean planting by 32,670 hectares, which leads to additional production of about 44.4 thousand MT (with yield $1.36 \mathrm{MT} / \mathrm{ha}$ ). In such case Russian soybean producers would reap an additional $\$ 22 \mathrm{mln}$.

\begin{tabular}{|c|c|c|c|c|}
\hline \multirow{2}{*}{$\begin{array}{c}\text { Income benefit } \\
\text { per hectare }\end{array}$} & \multicolumn{4}{|c|}{ Adoption rate } \\
\cline { 2 - 5 } & $25 \%$ & $50 \%$ & $75 \%$ & $100 \%$ \\
\hline$\$ 1$ & 0.18 & 0.36 & 0.54 & 0.72 \\
\hline$\$ 10$ & 1.8 & 3.6 & 5.4 & 7.2 \\
\hline$\$ 20$ & 3.6 & 7.2 & 10.8 & 14.4 \\
\hline$\$ 30$ & 5.4 & 10.8 & 16.2 & 21.6 \\
\hline$\$ 40$ & 7.2 & 14.4 & 21.6 & 28.8 \\
\hline$\$ 50$ & 9.0 & 18.0 & 27.0 & 36.0 \\
\hline$\$ 60$ & 10.8 & 21.6 & 32.4 & 43.2 \\
\hline$\$ 70$ & 12.6 & 25.2 & 37.8 & 50.4 \\
\hline$\$ 80$ & 14.4 & 28.8 & 43.2 & 57.6 \\
\hline$\$ 90$ & 16.2 & 32.4 & 48.6 & 64.8 \\
\hline
\end{tabular}

Source: own processing

Table 1. Estimated impact on producer's welfare with GM HT corn application in Russia (Millions of USD). 


\begin{tabular}{|c|c|c|c|c|}
\hline \multirow{2}{*}{$\begin{array}{c}\text { Income benefit } \\
\text { per hectare }\end{array}$} & \multicolumn{4}{|c|}{ Adoption rate } \\
\cline { 2 - 5 } & $25 \%$ & $50 \%$ & $75 \%$ & $100 \%$ \\
\hline$\$ 4$ & 0.45 & 0.90 & 1.35 & 1.79 \\
\hline$\$ 20$ & 2.24 & 4.49 & 6.73 & 8.97 \\
\hline$\$ 35$ & 3.93 & 7.85 & 11.78 & 15.71 \\
\hline$\$ 50$ & 5.61 & 11.22 & 16.83 & 22.44 \\
\hline$\$ 65$ & 7.29 & 14.58 & 21.88 & 29.17 \\
\hline$\$ 80$ & 8.97 & 17.95 & 26.92 & 35.90 \\
\hline$\$ 95$ & 10.66 & 21.31 & 31.97 & 42.63 \\
\hline$\$ 110$ & 12.34 & 24.68 & 37.02 & 49.36 \\
\hline$\$ 125$ & 14.02 & 28.04 & 42.07 & 56.09 \\
\hline$\$ 140$ & 15.71 & 31.41 & 47.12 & 62.82 \\
\hline$\$ 149$ & 16.71 & 33.43 & 50.14 & 66.86 \\
\hline
\end{tabular}

Source: own processing

Table 2. Estimated impact on producer's welfare with GM HT soybeans application in Russia (Millions of USD).

\section{Discussion}

Creation of a law to allow GM seeds and products to enter the market is not the only issue. Policymakers should also think about the procedure of admittance such products to allow producers to reap aforementioned benefits and guarantee food safety for consumers.

Around the world, current legislative practices with regard to GM products can be differentiated between two, rather extreme principles: substantial equivalence principle that treats GM as conventional food technology (OECD, 1992), as is applied in the U.S.; and precautionary principle that says in the case of a lack of scientific evidence it is better to ban a product that could be safe than accept one that could be dangerous (McGarity, 2001), as is applied in Europe. Most countries' legislation with respect to GM food falls between these two extremes (Chen, 2006). The precautionary principle hinders European growers to use GM technology, but this could change in the near future with extend of GM use in the Regulation on Genetically Modified food and feed (EC, 2015).

The author believes that politicians should construct rules with respect to GM technologies in a way to provide the necessary information to consumers and at the same time does not unequally disadvantage producers who wish to use GM or conventional products. The public is very sensitive to such issues and would rather avoid GM products. In this case labeling will play the major role.

With regards to labeling, studies reveal that when GM labeling is voluntary or mandatory, the outcome is equal (Bansal and Gruère, 2010). In the case of the type of labeling, rules should transparently define which products can be assigned as GM. Three categories of such products have to be determined:

1. GM food for direct consumption;

2. Food for animal feed that is later converted to other type of products;

3. GM food that is processed and can be sold for direct consumption or for use in production of other products.

Common practices of labeling the aforementioned categories are: GM food for direct consumption is labeled as being a GM food. Japan offers a good example of labeling the second and third categories: "Exempted processed foods are products such as those in which recombinant DNA or proteins produced by such DNA are finally eliminated or broken down..." (FAQ, 2003). In other words, if DNA of genetically modified product is broken such product should not be labeled as GM. With regards to the third category, Chinese law requires labeling products as GM if the share of GM ingredients is more than 5\% (Chen, 2006).

Definition of GM foods can be adjusted with legislation. But should non-GM food be labelled as well? This question is more difficult. In the case of Switzerland, 'GMO-free' labeling is prohibited because it is difficult to guarantee $0 \%$ GMO in the food (Regulation, 1997). This point is valid given the difficulty of separating GM and non-GM products during planting, transportation, and processing.

The aforementioned legislative practices can be adapted to the Russian case as well. Proper labeling of GM products will provide sufficient information to consumers, while not harming producers of GM products. 
Government policy in regards to handling and storage of GM products will impact the welfare effect from the technology. Additional costs will rise with the necessity to document, verify and separate transport and storage facilities for GM and non-GM products. However, the size of such additional costs depends on the crop, volume and the threshold level of contamination accepted (Stone et al., 2002).

Many authors have estimated such costs. For example, Buckwell et al. (1999) find that for the US market with tolerance level of GM residues of $1 \%$, additional costs were approximately $10 \%$ of farm gate prices. With this same tolerance level in Russia, it would require almost $\$ 87$ per ha of corn and $\$ 68.7$ per ha of soybeans. Interpreting these results, costs for GM corn handling are higher than most values of income benefits per ha seen in Table 1, which means that considering the handling and storage costs of GM HT corn can result in welfare losses. For soybeans additional costs are in the middle range of income benefits from the GM technology (Table 2), and so large welfare gains can occur. Aforementioned costs are calculated for the first period of GM introduction. Over time costs are expected to fall as procedures improve (Buckwell et al., 1999).

Another source (Leading Dog Consulting, 2001) presents an estimation from Australia, where additional costs for testing technology, segregation and identification systems will increase by $10-15 \%$ through the supply chain. Vandenberg et al. (2000) used a linear programming approach to evaluate different scenarios of segregation for existing GM corn and soybeans on the market and found that the total costs of the supply chain will increase in the range by $3-9 \%$. The European Commission (2000) estimated the costs will increase by $6-17 \%$ of the farm gate price.

Estimations of additional costs related to GM crop treatment vary and depend on the particular country case and chosen policy applied to the GM products. These estimations demand careful calculation as the additional costs in the supply chain can potentially cancel out the producers' welfare increase from the cost-saving technology.

The state can support farmers not only by subsidies, but opportunity to produce cheaper and, therefore, larger quantity of products and reap higher profits with GM introduction. Unlike subsidies, which are a redirection of financial resources from other sectors, producers will gain from free access to GM products without large state expenses. Additional welfare gains will accelerate soy and corn production.

\section{Conclusion}

The paper presents the possible gains to Russian producers from opening the market to GM seeds, in particular HT corn and soybean seeds. The term "producer" in this context does not refer to only farmers. Farmers share total producer welfare with other players in the inputs market. Lifting the GM ban will lead to a multiplier effect that touches all related industries.

Allowing GM technologies will not only affect producers who choose to plant GM seeds, but conventional growers as well. Seed companies will have to decrease the price of conventional seeds to compete with the new product. The same direction of price policy will adhere to retail companies who sell herbicide products for treatment of conventional varieties.

This paper examined the direct monetary effects only. However, GM crops lead to other benefits as well: the reduced tillage with HT crops leads to less machinery costs and release of machines for other operations; reduction in the amount of crop protection (or change to a less dangerous class of chemicals), which leads to environmental and health benefits. In addition, an increase of soybean production will lead to higher selfsufficient levels for this crop, which is a very important issue for Russian politicians.

Lifting the GM ban in Russia may lead to a considerable increase in the welfare of producers. Only taking into account these two GM crops: corn and soy (assuming a 50\% adoption rate and income benefits of $\$ 30$ and $\$ 50$ for corn and soy, respectively) results in income benefits equal to the current government subsidies for purchasing elite seeds (MCX, 2015).

The author does not intend to declare unambiguously that lifting the ban on GM products only yields benefits. Introduction of GM products will require developing and applying an identification and labeling system for GM and non-GM products, which can outweigh potential benefits. Environmental and health issues, as well as possible changes in the influence and market shares of multinational seed companies, should also be considered carefully. A comprehensive analysis of all pros and cons should be done as soon as possible so that Russia does not lose out on the potential welfare gains that are partly discussed in this paper. 


\section{Acknowledgements}

The author is grateful to Prof. Dr. Klaus Salhofer for very helpful comments and advice on an early draft of this paper and to Elizabeth Lunik for advice and language corrections of the paper.

\author{
Corresponding author: \\ Sergey Chetvertakov \\ Institut für Betriebswirtschaft, Bundesallee 50,38116 Braunschweig, Germany \\ E-mail: chetvertakovsergey@gmail.com
}

\title{
References
}

[1] Bansal, S., Gruère, G. (2010) „Labeling genetically modified food in India: economic consequences in four marketing channels“ (No. 946), International Food Policy Research Institute (IFPRI).

[2] Baute, T. S., Sears, M. K., and Schaafsma, A. W. (2002). „Use of transgenic Bacillus thuringiensis Berliner corn hybrids to determine the direct economic impact of the European corn borer (Lepidoptera: Crambidae) on field corn in Eastern Canada." Journal of economic entomology. Vol. 95, No. 1, pp. 57-64. ISSN 0022-0493.

[3] Brookes, G., Barfoot, P. (2014) „Economic impact of GM crops“, GM Crops \& Food, Vol. 5, No. 1, pp. 65-75. ISSN 2164-5698, E-ISSN 2164-5701, DOI: 10.4161/gmcr.28098.

[4] Buckwell, A., Brooks, G. Bradley, D., Barfoot, P., Tangermann, S. and Blom, J. (1999), Economics of Identify Preservation for Genetically Modified Crops“, Final Report of a study for Food Biotechnology Communications Initiative, Wye College, England.

[5] Chen, Christopher C. (2006) „Labeling Genetically Modified Food - Comparative Law Studies from Consumer's Perspective“, National Taiwan University Law Review, Vol. 1, No. 1. [Online]. Available: http://ssrn.com/abstract=1832138 [Accessed 30 March 2015].

[6] EC (2015) Speaking points on Regulation on Genetically Modified food and feed - Council of the EU - Agriculture and Fisheries, European commission, 13 July 2015. [Online]. Available: https://ec.europa.eu/commission/2014-2019/andriukaitis/announcements/speaking-pointsregulation-genetically-modified-food-and-feed-council-eu-agriculture-and-fisheries_en [Accessed 20 July 2015].

[7] European Commission (2000) Economic Impacts of Genetically Modified Crops on the Agri-Food Sector, Directorate-General for Agriculture, March 2000.

[8] FAPRI (2015) Elasticity Database, Food and Agricultural Policy Research Institute. [Online]. Available: http://www.fapri.iastate.edu/tools/elasticity.aspx [Accessed 18 March 2015].

[9] FAQ (2003) „FAQs on Labeling System for Genetically Modified Foods“ [Online]. Available: http:// www. mhlw.go.jp/english/topics/qa/gm-food/gm1.html [Accessed 02 January 2003].

[10] Finger, R., El Benni, N., Kaphengst, T., Evans, C., Herbert, S., Lehmann, B., Morse, S., Stupak, N. A . (2011) „Meta Analysis on Farm-Level Costs and Benefits of GM Crops“, Sustainability, Vol. 3, No. 5, pp. 743-762. ISSN 2071-1050, DOI: 10.3390/Su3050743.

[11] Gov (2015a) The distribution of subsidies in 2015 to support agriculture, The Russian Government, [Online]. Available: http://government.ru/docs/16916/ [Accessed 18 March 2015].

[12] Gov (2015b), The plan of priority measures to ensure the sustainable economic development and social stability in 2015, The Russian Government. [Online]. Available: http://government.ru/ docs/16639/ [Accessed 18 March 2015].

[13] Kommersant (2015) The Russian government approved a ban on GMOs, ИД «Коммерсантъ», [Online]. Available: http://www.kommersant.ru/doc/2658384 [Accessed 15 March 2015].

[14] Leading Dog Consulting and Peter Flottmann and Associates (2001), Segregating Gene Technology Products - Requirements, Costs and Benefits of Identity Preservation, Segregation and Certification, Prepared for Commonwealth Department of Agriculture, Fisheries and Forestry, May. 
[15] Lenta (2015) The bill of a ban on cultivation of GMO in Russia is introduced in the State Duma, «Лента.Ру» интернет-газета, [Online]. Available: http://lenta.ru/news/2015/02/03/gmo/ [Accessed 15 March 2015].

[16] McGarity, T. O. (2001) Seeds of Distrust: Federal Regulation of Genetically Modified Foods, U. mich. JL reform, 35 Univ.of Mich. J. L. Reform 403.

[17] MCX (2015) Distribution of subsidies in the directions of the state support, Ministry of Agriculture of the Russian Federation. [Online]. Available: http://www.mcx.ru/documents/document/v7 show/31252..htm [Accessed 26 April 2015].

[18] MEDRF (2012) The draft of the resolution of the Russian Federation government "About the statement of the Order of the state registration of the gene engineering modified organisms intended for release in environment, and also the production received with application of such organisms or containing such organisms", Ministry of Economic Development of the Russian Federation. [Online]. Available: http://economy.gov.ru/minec/about/structure/ depregulatinginfluence/doc20121229_07 [Accessed 20 February 2015].

[19] Moschini, G., Lapan, H., Sobolevsky, A. (2000) „Roundup Ready® soybeans and welfare effects in the soybean complex", Agribusiness, Vol. 16, No. 1, pp. 33-55. E- ISSN: 1520-6297. DOI: 10.1002/(SICI)1520-6297(200024)16:1<33::AID-AGR4>3.0.CO;2-5

[20] OECD (1992) Safety Evaluation of Foods Derived by Modern Technology: Concept and Principle 1992.

[21] Potemkina, V. I., Lastushkina, E. N. (2006) „Asiatic corn borer (ostrinia furnacalis gn.) (lepidoptera, pyralidae) and the role of biotic factors on its decline in primorye region", A.I. Kurentsov's Annual Memorial Meetings, Vol. 17, pp. 107-113.

[22] Raney, T. (2006) „Economic impact of transgenic crops in developing countries“. Current Opinion in Biotechnology. Vol. 17, No. 2, pp. 174-178. ISSN 1369-5274, DOI 10.1016/j.copbio.2006.02.009.

[23] Regulation (1997) Regulation (EC) No 258/97 of the European Parliament and of the Council of 27 January 1997 concerning novel foods and novel food ingredients, European Union law, No. 258/97, O.J. (L 043) 1.

[24] Serapionov, D.A., Frolov A.N. (2008) „Maize infestation by the $1^{\text {st }}$ generation European corn borer larvae and precipitation in May at the Krasnodar area: GIS mapping and georeferencing", Plant Protection News. Vol. 2, pp. 34-37. ISSN 1815-3682.

[25] Stone, S., Matysek, A. and Dolling, A. (2002) „Modelling Possible Impacts of GM Crops on Australian Trade“, Productivity Commission Staff Research Paper, Melbourne, October.

[26] Trigo, E. J., Cap, E. J. (2004) „The impact of the introduction of transgenic crops in Argentinean agriculture“, AgBioForum, Vol. 6, No. 3, pp. 87-94. [Online]. Available: http://www.agbioforum. org [Accessed 7 April 2015].

[27] UN Comtrade Database (2015) United Nations, [Online]. Available: http://comtrade.un.org/ [Accessed 3 March 2015].

[28] UniSis database (2015) Unified Interdepartmental Statistical Information System. [Online]. Available: http://www.fedstat.ru/indicators/start.do [Accessed 20 March 2015].

[29] USDA database (2015) Production, Supply and Distribution, United States Department of Agriculture Foreign Agricultural Service. [Online]. Available: http://apps.fas.usda.gov/psdonline/ psdQuery.aspx [Accessed 17 March 2015].

[30] Vandenberg, J. M., Fulton, J. R., Dooley, F. J., and Preckel, P. V. (2000) „Impact of identity preservation of non-GMO crops on the grain market system". CAFRI: Current Agriculture, Food and Resource Issues. Vol 01. 